\title{
Proměny práce školních psychologů v proinkluzivně naladěných školách ${ }^{1}$
}

\author{
Bohumíra Lazarová, Lenka Hloušková, Milan Pol, \\ Kateřina Trnková
}

\author{
Masarykova univerzita, Filozofická fakulta, Ústav pedagogických věd \\ Redakci zasláno 20. 3. 2017 / upravená verze obdržena 30. 6. 2017 / \\ k uveřejnění přijato 4. 7. 2017
}

\begin{abstract}
Abstrakt: Jednou z možností, jak lze podporovat školy v jejich směřování k inkluzivnímu vzdělávání, je posilování odborného potenciálu škol skrze ustavování nových, poradensky orientovaných funkcí pedagogických pracovníků či dalších specialistů. Mezi tyto specialisty bezesporu patří i školní psychologové a naším záměrem v tomto textu je přiblížit, jak inkluzivní směřování škol proměňuje náhled školních psychologů na svou práci. Na základě empirických dat (vícečetná případová studie) ze dvou základních proinkluzivních škol popíšeme, jak školní psychologové reflektují svou práci, jak vnímají (staro)nová očekávání učitelů i vedení svých škol a jak nahlížejí vlastní roli v podpoře školy při zvládání zvyšující se diverzity žáků.
\end{abstract}

Klíčová slova: inkluzivní vzdělávání, školní psycholog, školní poradenství, základní škola

Navzdory tomu, že téma inkluzivního vzdělávání je již léta středem pozornosti politiků, odborné i laické veřejnosti a že existuje řada odborných publikací i příkladů dobré praxe, zůstává inkluzivní či v českém školství tzv. společné vzdělávání do jisté míry kontroverzním tématem. Prosazování ideálu inkluze ve školním prostředí totiž s sebou přináší minimálně dvě hlavní pochybnosti. První se týká výkladu a chápání samotného konceptu, tedy vyjasňování toho, jakou podobu má mít inkluzivní vzdělávání, což v reálných podmínkách, a to nejen českých základních škol, vyvolává otázku únosné či spíše reálně zvládnutelné míry diverzity žákovské populace. Důraz na individuální potřeby každého z žáků či „skupin žáků“, v důsledku kterého reálně či pomyslně roste diverzita žákovské populace, mění a zřejmě i nadále bude

\footnotetext{
1 Výzkum, na jehož základě vznikl tento text, byl podpořen Grantovou agenturou MU v rámci projektu Inkluze ve škole jako interdisciplinární problém. Východiska, podmínky a strategie realizace (GA MU MUNI/M/0012/2013).
} 
měnit charakter práce lidí ve škole (Anthun \& Manger, 2006; Farrell, 2004; Lazarová et al., 2015).

Druhá pochybnost se týká procesů, které skutečně podporují naplňování principů inkluzivního vzdělávání v různých edukačních kontextech a situacích, tj. jak je možné tuto sdílenou představu úspěšně naplňovat (Allan, 2008; Florian, 2008; Lazarová et al., 2015). Snahy spolehlivě identifikovat faktory a intervence, které by podpořily školy nebo pedagogické pracovníky v jejich směřování $\mathrm{k}$ inkluzivnímu vzdělávání, jsou přitom mnohdy úspěšné jen zčásti. Jednou z typicky uplatňovaných strategií podpory škol v tomto směru je posilování odborného potenciálu škol skrze ustavování funkcí poradců a jiných specialistů, jako jsou školní psychologové, školní speciální pedagogové, asistenti pedagoga, př́padně i sociální pedagogové, sociální pracovníci a podobně (Farrell, 2004). Také v České republice se $\mathrm{k}$ této strategii uchylujeme, nebot' i v našich podmínkách je opakovaně dokladováno, že naplňování ideálu inkluzivního vzdělávání je přímo úměrné míře kvalifikovanosti pedagogických pracovníků a posílení dostupnosti poradenských kapacit přímo ve školách (např. Analýza, 2009; APIV, 2015).

O tom, že posilování odborného potenciálu škol je žádoucí strategií, není pochyb, ale nás zajímá, s čím konkrétně se školní psychologové v proinkluzivně nastavených školách potýkají, s čím pomáhají a jak se podle jejich názoru proměňuje jejich práce i role ve škole. Na základě empirických dat ze dvou úplných základních škol Jihomoravského kraje, které se dlouhodobě snaží uplatňovat principy inkluzivního vzdělávání, ukážeme, jak školní psychologové reflektují svou práci, jak vnímají (staro)nová očekávání učitelů i vedení svých škol a jak nahlížejí vlastní roli v podpoře školy při zvládání zvyšující se diverzity žáků.

\section{Inkluzivní vzdělávání jako podnět ke změnám v práci školních psychologů}

Inkluzi jako nové výzvě pro školní psychology se v psychologické komunitě věnuje pozornost již delší dobu (AEP, 1999; Farrell, 2006; Kershner \& Farrell, 2009). V této souvislosti se také znovu otevírá otázka náplně práce školních psychologů, která je v obecné rovině obvykle zakotvena v legislativě, ale

2 V tomto textu píšeme o „školách směřujících k inkluzivnímu vzdělávání“ nebo o „proinkluzivních školách", nebot' inkluzi chápeme jako proces, stejně tak jako ideál, ke kterému škola neustále směřuje. 
pro praxi je příznačná poměrně velká rozmanitost a široký záběr. Podle základních zdrojů (Asociace, nedatováno; Vyhláška č. 197/2016; Zapletalová, 2001) je očekávaná náplň práce českých školních psychologů vymezována:

- výčtem potřeb cílových skupin, se kterými školní psycholog pracuje (žáci, rodiče, učitelé, vedení školy), a to v individuální i skupinové podobě, přičemž se zdůrazňuje práce se školou jako systémem;

- typickými druhy činností (diagnostika a různé typy intervencí, jako např. nápravy či konzultace, ale také výzkum či evaluace a monitoring);

- nebo tématy, kterým školní psycholog nejčastěji věnuje pozornost, a to jak v oblasti primární, tak sekundární prevence (např. různé druhy rizikového chování či patologie, jako je ADHD, agrese, šikana, vývojové poruchy učení, orientace na sociální klima či v posledních letech spíše na zdraví ve školách apod.).

Reálná náplň práce je ale určena specifickým vzděláním, schopnostmi a profesním zájmem každého školního psychologa a především tím, v jakém školním prostředí pracuje a jaké požadavky jsou na něj kladeny ze strany školy.

Nahlédneme-li náplň práce školních psychologů skrze dvě základní pojetí inkluzivního vzdělávání, pak v duchu psycho-medicínského pojetí inkluze, které je charakteristické zdůrazňováním speciálních vzdělávacích potřeb některých žáků (Bartolo, 2010; Mitchell, 2005; Soodak, 2003), dominuje akcent na podporu žáků se speciálními vzdělávacími potřebami, i když v širokém slova smyslu. Od školního psychologa se v tomto případě vyžaduje využívání klasických klinických př́stupů, jako je diagnostika a podpora změny jedince - žáka se speciálními vzdělávacími potřebami - s cílem pomoci mu obstát v prostředí běžných škol, což je ale charakteristické spíše pro integrační procesy. Všeobecný odklon od tohoto pojetí inkluze s sebou přinesl požadavek na redukci klasických klinických přístupů a důraz na sociální změnu - změnu hodnot, postojů a perspektiv všech aktérů ve školách i mimo ně. ${ }^{3}$

Pokud jde o odklon od psycho-medicínského pojetí, pak jsou školní psychologové v českém prostředí méně zatíženi svou minulostí. Opomineme-li první zmínky o školní psychologii z 30. let (např. Ohera, 1936), hned v porevolučních odborných debatách o nové podobě české školní psychologie vlivní autoři (např. Mareš, 1998; Štech \& Zapletalová, 2001) zdůrazňovali systémový přístup a orientaci na klima školy a varovali před silným zaměřením na diagnostiku žáků. 
Dnes převažující psycho-sociální pojetí inkluze od školních psychologů vyžaduje, aby nahlíželi jednotlivé třídy a školu jako systémy a aby jednotlivé žáky pojímali jako součást daného kulturního kontextu, který je determinován neustále se měnícími interakcemi a vztahy (srov. Berger \& Luckmann, 1996; Farrell, 2006). To znamená, že i různá znevýhodnění či poruchy vývoje, byt' některé z nich mohou mít biologický základ, jsou nahlíženy jako rizikové faktory, které mohou být rozvíjeny či tlumeny působením sociálního prostředí. Školní psychologové se tedy mohou podílet na odstraňování stigmat tím, že usilují o změny v chápání sociálně zkonstruovaných významů, které lidé ve škole vztahují k různým znevýhodněním. Tím mohou výrazně ovlivňovat postoje druhých ve školách i mimo ně a bojovat tak např́klad proti diskriminaci určitých skupin žáků a jejich rodin. Ve školněpsychologické praxi tedy nabývá na významu péče o sociální klima školy a tř́́d, podpora komunikace mezi nejrůznějšími aktéry vzdělávání a v neposlední řadě i reflexe praxe učitelů a dalších pedagogických pracovníků školy (např. Bartolo, 2010).

Farrell $(2004$, s. 11) dokonce konkretizuje některé úkoly a činnosti školních psychologů v zájmu podpory inkluzivního vzdělávání. Školní psychologové mohou například předávat kolegům ve škole informace o nejnovějších výzkumech, podporovat asistenty pedagogů, vysvětlovat rodičům i učitelům potenciální zisky inkluzivního vzdělávání či inovovat individuální vzdělávací programy/plány. Pokládá za nutné, aby školní psychologové učitelům pomáhali reflektovat jejich praxi, plánovat a realizovat změny a přispívat tak $\mathrm{k}$ rozvoji školy ku prospěchu všech žáků. Za jeden $\mathrm{z}$ nejdůležitějších úkolů však uvedený autor považuje práci na úrovni celé školy a snahu o podporu organizační změny.

V souvislosti s podporou inkluzivního vzdělávání hovoří Adelman a Tylor $(2003,2014)$ o tom, že školní psychologové by se měli méně zabývat výkony žáků a více směřovat $\mathrm{k}$ podpoře pocitu pohody (well-being) a vytváření vhodného klimatu ve škole a okolo ní. Od školních psychologů se ale také očekává, že budou vytvářet a uplatňovat specifické intervence založené na důkazech (evidence-based interventions), které viditelně podpoří inkluzivní prostředí ve školách i v jejich bezprostředním okolí (White \& Kratochwill, 2005).

Ukazuje se, že snahy o hlubší pochopení a popis role školních psychologů v dnešních školách již neaspirují na výčty pracovních činností, ale spíše se zdůrazňuje potřeba pečlivě „naslouchat škole a jejím aktérům“, což je považováno za východisko pro náplň práce školních psychologů „šité škole a učitelům na míru" (např. Braden, DiMarino-Linnen, \& Good, 2001). Také současná 
česká odborná literatura rozvíjí tuto linii uvažování o náplni práce školních psychologů a bere v úvahu, že v souvislosti s požadavkem inkluzivního vzdělávání se i u nás postupně mění podoby a potřeby škol, $v$ důsledku čehož lze očekávat, že se bude měnit charakter práce školních psychologů (Braun, Marková, \& Nováčková, 2014; Štech \& Zapletalová, 2013).

\section{Z metodologie výzkumného šetření}

Jak jsme již uvedli, pro účely této studie vycházíme z výsledků výzkumu, který jsme realizovali v letech 2013 až 2015 v rámci projektu s názvem Inkluze ve škole jako interdisciplinární problém - východiska, podmínky a strategie realizace. Cílem uvedeného projektu bylo zkoumat inkluzivní vzdělávání pohledem různých vědních disciplín a náš tým z Ústavu pedagogických věd Filozofické fakulty Masarykovy univerzity se zaměřil na zkoumání procesů řízení a vedení, které podporují inkluzivní vzdělávání.

Pro realizaci tohoto výzkumu jsme zvolili cestu vícečetných př́ípadových studií, které jsme realizovali ve třech běžných úplných základních školách Jihomoravského kraje. Školy jsme vybrali podle několika kritérií: běžné základní školy se stabilním vedením (ředitel školy nejméně pět let ve své funkci), školy středně velké (minimálně dvě paralelní třídy v ročníku) s relativně dobrou pověstí (dle inspekčních zpráv a expertních posouzení), školy, které se neprofilovaly př́mo jako „inkluzivní školy“, ale měly bohaté zkušenosti se zvládáním diverzity žáků nejen ze spádových oblastí. Posledním kritériem výběru škol byla dostupnost poradenských služeb. Toto kritérium jsme pojali jako diferenciační prvek mezi školami, tj. vybrali jsme školu s personálně silně obsazeným školním poradenským pracovištěm ( 5 členů), školu s „klasickým“ složením školního poradenského pracoviště (3 členové) a školu, kde působí pouze výchovný poradce a školní metodik prevence, přičemž psychologické i speciálněpedagogické služby jsou žákům i učitelům dostupné přibližně v 10 kilometrů vzdáleném městě.

Za účelem sběru dat jsme ve všech třech školách využili kombinaci několika metod. Stěžejní metodou byly hloubkové a polostrukturované rozhovory $\mathrm{s}$ vedením školy (vždy dva rozhovory alespoň s jedním členem užšího vedení školy), polostrukturované rozhovory s učiteli, s výchovným poradcem, školním psychologem, vždy s jednou z vychovatelek školní družiny a jedním $\mathrm{z}$ asistentů pedagoga. Kromě toho jsme administrovali mírně upravený ${ }^{4}$

4 Úprava spočívala $v$ přeformulování některých položek. Zachovali jsme však strukturu nástroje i způsob jeho vyhodnocení (více viz Lazarová et al., 2015). 
dotazník Připravenost školy k inkluzivnímu vzdělávání (Lukas, 2012), jehož základ představuje Index for Inclusion (Booth \& Ainscow, 2007)5. Data získaná touto cestou jsme podpořili analýzou dokumentů jednotlivých škol (např. školních vzdělávacích programů, webových stránek škol a dalších specifických dokumentů).

$\mathrm{V}$ tomto textu pochopitelně pracujeme $\mathrm{s}$ daty pouze ze dvou zkoumaných škol, které na plný pracovní úvazek zaměstnávaly vždy jednoho školního psychologa, resp. školní psycholožku. Ve snaze anonymizovat a zpřehlednit publikování dat jsme školám dali pracovní názvy: škola Skleněná a škola Lesní. ${ }^{6}$

Škola Skleněná je velkoměstskou sídlištní základní školou a v době sběru dat ji navštěvovalo zhruba 500 žáků. Naprostá většina těchto žáků pocházela ze spádové oblasti. Z hlediska socio-ekonomického postavení se ve škole setkávají sídlištní děti z rodin střední a nižší sociální třídy, děti z ekonomicky dobře situovaných rodin i děti ze sociálně znevýhodněného prostředí (tím máme na mysli děti, které přechodně žijí v zařízení pro děti vyžadující okamžitou pomoc a děti pocházející ze sociálně velmi slabých rodin). $Z$ etnického a národnostního hlediska je žákovská populace složena především (i když ne výhradně) z př́slušníků majority, jejímž mateřským jazykem je čeština. Skladba žákovské populace je ale pestrá, pokud jde o žáky s potřebou podpůrných opatření. Jsou zde zastoupeni žáci s potřebou podpůrných opatření z důvodu tělesného, mentálního či kombinovaného postižení, specifických poruch učení a chování, poruch autistického spektra, narušené komunikační schopnosti, ale i žáci nadaní či žáci-cizinci. V prvním ročníku, a v některých letech i ve druhém, je otevřena speciální třída pro žáky s poruchami komunikačních schopností, tzv. skupinová integrace. Poradenské služby ve škole zajišt’ují vedle školní psycholožky i výchovná poradkyně, metodička prevence, poradkyně pro volbu povolání a školní speciální pedagožka.

Škola Lesní se nachází na kraji městyse o dvou tisících obyvatelích a opět, $\mathrm{v}$ době sběru dat do ní docházelo přibližně 500 žáků z blízkých i vzdálenějších obcí, přičemž se výrazně liší počet žáků na prvním a druhém stupni. Populace žáků se podobně jako v př́ípadě školy Skleněné vyznačuje značnou

\footnotetext{
V tomto textu data z dotazníku využíváme sporadicky, nebot' se přímo nevztahovala k práci školních psychologů.

6 Jako třetí byla vybrána škola se zhoršenou dostupností psychologických služeb (nezaměstnávala školního psychologa). Této škole z pochopitelných důvodů nebudeme v textu věnovat pozornost.
} 
heterogenitou, ale v trochu jiné podobě. Specifikem žákovské populace školy Lesní je heterogenita vyplývající prioritně ze socioekonomického původu žáků, která je umocněna i širokou spádovostí školy (školu navštěvují děti z ekonomicky velmi slabých rodin, děti z nedalekého dětského domova, žáci „migrující" se svými rodiči, kteří opakovaným stěhováním řeší své životní nesnáze, na druhý stupeň přichází relativně hodně žáků z málotřídních škol). Vedle toho škola zřizuje i tzv. integrované třídy pro žáky s lehkým mentálním postižením. Poradenské služby zde zajišt'uje vedle školní psycholožky i výchovná poradkyně a metodička prevence.

Pro zvýšení validity dat z uvedených dvou škol jsme na jaře roku 2016 získaná data doplnili o postřehy šesti vybraných školních psychologů, které jsme pozvali do ohniskové skupiny. Kritériem výběru školních psychologů do ohniskové skupiny byla jejich minimálně dvouletá zkušenost $\mathrm{s}$ působením na základních školách a ve všech př́ípadech šlo o psychology účastnící se pravidelných setkání školních psychologů v Jihomoravském kraji. Tyto školní psychology jsme nejprve požádali o prostudování první verze kategorizace dat a následně jsme s nimi diskutovali (ve struktuře príjetí - odmítnutí či změna - doplnění dat) náš výzkum i naše interpretace. Výsledkem této diskuse pak bylo zpřesnění některých interpretací a doplnění dat, které jsou zapracovány dále v textu.

\section{Dopady inkluzivního vzdělávání na práci školních psychologů - z výsledků výzkumu}

Fakt, že proinkluzivní směřování školy ovlivňuje práci školních psychologů, se nám začal vynořovat $\mathrm{z}$ dat, když jsme na jednotlivých školách sledovali procesy řízení a vedení. Zpočátku se jednalo pouze o „potvrzení“ teze, že bez podpory ze strany školních psychologů je $\mathrm{v}$ běžných školách tzv. společné vzdělávání jen obtížně realizovatelné a pro některé aktéry našich škol až nepředstavitelné. S ohledem na to jsme si v průběhu sběru dat začali klást i další (specifické výzkumné) otázky týkající se práce poradenských pracovníků a specialistů ve škole. Dále v textu ale představíme jen odpovědi na otázky směřující k práci školních psychologů, které zastřešujeme otázkou: Jaké jsou stěžejní úkoly školních psychologů v proinkluzivně naladěných školách?

Vycházíme především $\mathrm{z}$ výpovědí školních psychologů a lidí z užšího vedení škol (ředitelů škol a jejich zástupců) a výsledky analýz představujeme v dualitě toho, jak školní psychologové reflektují svoji práci a jak vnímají očekávání 
učitelů i vedení svých škol. Reflexe školních psychologů pokrývá různé aspekty jejich práce, konkrétně jejich pozici ve škole, vztahy s učiteli, charakter i obsah práce. Interpretací dat zpracovávanou napříč oběma školami se snažíme upozornit nejen na osvědčující se školněpsychologickou praxi v proinkluzivním prostředí škol, ale i na její mnohá úskalí a rizika. Na základě uvedeného strukturujeme text do pěti aspektů, které stejně jako aktéři z námi zkoumaných škol i následně dotázaní školní psychologové v rámci ohniskové skupiny považují za ty aspekty své práce, jež se proměňují právě v souvislosti s prosazováním inkluzivního vzdělávání a zejména se vzrůstající diverzitou žákovské populace na základních školách.

Silný hlas psychologa: vyšší prestiž, ale vztahové riziko

Proinkluzivní politika státu a v důsledku toho i tlak na školy, aby byly ochotné přijímat všechny žáky bez ohledu na jejich znevýhodnění, automaticky nepřináší stejné a na té které škole sdílené porozumění konceptům inkluze či inkluzivního vzdělávání. Lidé ve školách si o inkluzi vytvářejí různé představy a k vizím svých škol deklarujících, že jsou školami pro všechny a zvládají diverzitu žákovské populace, zaujímají různé postoje, včetně těch negativních. ${ }^{7}$

Vedoucí pracovníci našich škol považují inkluzivní vzdělávání za žádoucí hodnotu i nutnost současně. Jejich pozitivní postoj $\mathrm{k}$ politice společného vzdělávání se na jednu stranu dá očekávat, ale ve hře (v době sběru dat) zůstávala i otázka naplněnosti školy. Protože ani jedna ze škol neměla naplněnou maximální kapacitu, obě se celkem ochotně otevíraly i žákům z jiných než spádových oblastí, kteří s sebou nesou pověst chápanou jako určité riziko. Vedení škol pak musí čelit mnoha resistencím učitelů a opakovaně vysvětlovat, či dokonce obhajovat svá rozhodnutí i s ohledem na pomoc ze strany školních psychologů.

„No někdy je to průšvih, samozřejmě, někdy mi učitelé řeknou ,Cos to zase nakoupil? Co jste to zas vzali?' Učitelé by chtěli děti hodný, chytrý, s obouma rodičema, který milujou školu." (ředitel školy Skleněné)

Na obou našich školách se školní psychologové ztotožňují s vizí své školy a ctí rozhodnutí vedení školy, na nichž sami často participují. Mají totiž silný hlas v rozhodování o tom, zda rizikového žáka, př́ípadně žáka s potřebou

7 Jen na okraj zde můžeme zmínit některá data z dotazníků: jasně deklarovanou proinkluzivní politiku na našich dvou školách vnímají pracovníci škol velmi silně. Podstatně hůře hodnotí připravenost vlastní školy, pokud jde o její kulturu. 
podpůrných opatření z jiné než spádové oblasti přijmout a do které třídy jej zařadit. To je pak staví do role obhájců rozhodnutí vedení školy ochotně přijímat i tyto rizikové žáky.

Symbolická otevřenost školních dveří však neznamená, že si vedení škol a školní psychologové neuvědomují limity inkluzivního vzdělávání. Ty se týkají zejména typu postižení žáka, ale i vybavenosti a připravenosti školy zvládat pestrou paletu individuálních potřeb, jejích tradic a zkušeností a v neposlední řadě i kompetencí učitelů.

„Já jako sám za sebe řeknu, že jsem odpůrcem toho, aby mentálně postižení žáci chodili do normální tř́idy. Samozřejmě bych se setkal s mnoha lidmi, kteří by mě kritizovali. Ted' je prostě můj názor takový. Na druhé straně jsem ale odpůrcem toho, aby chodili do nějaké školy někde na kopeček, a jsem velkým zastáncem toho, co máme tady [integrované tř́ídy pro mentálně postižené žáky - pozn. autorů]... všechno dělají společně." (ředitel školy Lesní)

Také Bartolo (2010, s. 575) připouští, že i školní psychologové - kteří obvykle zaujímají silně proinkluzivní postoje - přemýšlejí o limitech inkluzivního vzdělávání. Není možné, aby nereagovali na hlasy těch, kteří upozorňují na konkrétní rizika jak pro žáky, tak pro celé třídy a školy. V realitě školního života - a naše data to dokladují - také školní psychologové mnohdy jen obtížně hledají a nacházejí rovnováhu v dilematu, zda je užitečné všechny žáky s vážnějším postižením včlenit do hlavního proudu, či nikoli. Jejich úkolem na našich školách je pak zvážit všechna pro a proti, vzít ohled nejen na osobní možnosti jedince, ale i na celý sociální kontext, ve kterém žák žije a do kterého nově vstupuje, a svými znalostmi a zkušenostmi podloženými názory vstupovat do rozhodování užšího vedení školy.

„Když se dostávám $\mathrm{k}$ těm problematičtějším žákům, tak to zařazování do tř́́d má u nás na starosti vesměs paní psycholožka a paní výchovná poradkyně ve spolupráci s poradnama." (zástupce ředitele školy Lesní)

Školní psychologové tedy mají silný hlas při rozhodování o tom, zda v nejrůznějších ohledech rizikové dítě či dítě s potřebou podpůrných opatření do školy přijmout, za jakých podmínek a do které třídy je umístit. Společně $\mathrm{s}$ vedením školy ale také nesou odpovědnost za tato rozhodnutí. Tím v nich roste pocit „povinnosti“ vytvořit co nejlepší podmínky pro to, aby nebyl neadekvátním umístněním poškozen žák, ani jeho okolí. 


\begin{abstract}
„Školní poradenské pracovištěje obrovský dar pro školu, ale tedy musísamozřejmě pracovat. [...] Oni jsou odborníci, já tomu nerozumím, ona je vyštudovanej psycholog. [...] Nemůže jít suplovat, nemůžu ji pověřovat hovadinami, ona si dělá svoje podle nějakýho plánu, podle nějakých stanovenejch pravidel, kodexu. [...] Jsou tam prostě jasně nastavený pravidla, co může dělat, a co ne." (ředitel školy Skleněné)
\end{abstract}

Výše zmíněné tvrzení dokládá, že postavení školních psychologů jako expertních specialistů bude ve školách patrně nabývat na vážnosti a respektu. Naše data potvrzují, že školní psychologové mají vysokou profesní autonomii a vedení škol, chce-li využít jejich potenciálu, musí brát v úvahu jejich odbornost a ohlížet se na specifika jejich práce. Pokud mají poradenské služby fungovat (a tak tomu v našich školách bylo), vedení by mělo školním psychologům a jiným poradenským specialistům důvěřovat a samožrejmě i vytvářet prostor a podmínky pro jejich práci.

„To vedení nám dává hodně prostoru, takže není to zas až tak kontrolní. Že bychom třeba dávali pravidelné zprávy nebo tak, to není vyžadováno. Já už mu někdy sama dávám zprávy panu řediteli, jakoby za ŠPP [školní poradenské pracoviště - pozn. autorů], i když to nechce." (školní psycholožka školy Lesní)

Vzájemná důvěra, jistá „spoluzávislost“ a reciproční vztah mezi vedením a školními psychology však zvyšují riziko př́liš těsného napojení školních psychologů na vedení školy, což může jejich profesní roli i je osobně v očích učitelů zpochybňovat. To bývá umocněno případnými požadavky ze strany členů užšího vedení školy například na to, aby školní psycholog „dohlédl“ na situaci ve tř́íách s vysokým podílem rizikových žákủ. Zvláště rizikové se to školním psychologům jeví v případech, kdy ze strany některých rodičů přicházejí stížnosti na práci učitele, který - z jejich pohledu - nebere dostatečné ohledy na handicap dítěte. Školní psycholog se tak stává svědkem „učitelských chyb a nedostatků", a pokud je v očích učitelů důvěrníkem a spojencem užšího vedení školy, nebývá pro školní psychology jednoduché takové situace zvládat, zvláště vstupují-li do hry rodiče.

„No, já nechci dělat peklo na pracovišti. My máme ted'ka tady takový problém na prvním stupni, že paní učitelka tu tř́ídu nějak vede a ostatním se to nějak nelíbí, dokonce se tu šírí takové řeči, že by tu třídu měla vyměnit a tak. Pokud ta paní učitelka přijde, tak se bavíme. [...] Tak se snažíme něco najít, třeba od čeho by se dalo odpíchnout. Ale nešla bych v tom směru, že bych jí začala radit, to ne... No je to těžký to nějak ustát." (školní psycholožka školy Lesní) 
První charakteristika práce školních psychologů tedy odráží jejich posilněnou pozici - stávají se významným argumentem vedení v proinkluzivní politice školy. Spolurozhodování školních psychologů o přijímání a umistování rizikových žáků i žáků s potřebou podpůrných opatření do tř́id, formulace opatření a někdy vedením požadovaná „kontrola“ jejich naplňování však školní psychology vystavuje jistým vztahovým rizikům s učiteli - zvláště pak $\mathrm{s}$ těmi, kteří $\mathrm{k}$ inkluzi zaujímají negativní postoje. A právě ve vztazích s učiteli spatřujeme druhé téma k diskuzi.

\section{Vztahy s učiteli: blízkost a naslouchání}

Zvládání výukových a výchovných obtíží žáků s potřebou podpůrných opatření stojí učitele více starostí, více energie, více administrativy, pečlivější přípravy a jiné práce spojené s výukou. Školní psychologové, kteří se každý den s učiteli potkávají, tak nemohou „jednoduše“ přehlížet důkazy o zvyšující se náročnosti práce učitelů, a dokonce $v$ mnohých případech rozumí negativním postojům i rezistencím učitelů vůči zvyšující se diverzitě žáků, zvláště pokud nemají ve škole dobré materiální ani pracovní podmínky. Na základě toho je pak zcela pochopitelné, že školní psychologové vyjadřují porozumění pro zvýšenou zátěž učitelů a snaží se učitelům ulevovat. Sami školní psychologové sdělují, že mnohdy stačí jen naslouchat a vyjádřit pochopení bez aspirací na řešení komplikované situace. Učitelé totiž někdy ani neočekávají, že by jim školní psycholog dokázal v nesnadné situaci přímo a hned pomoci. Přicházejí si tedy k nim nezřídka jen pro podporu a úlevu.

„Jednou se mi stalo, že paní učitelka tady tak koukla jeden den a ted' nám to všechno vysypala, co všechno je hrozný a tak. A přišla druhý den a říkala, že byla tak strašně ráda, že mi to mohla říct, že to prostě jen potřebovala říct. [...] Někdy je to i o nějaké ventilaci přetížení, nevím si rady a tak." (školní psycholožka školy Skleněné)

„No, tak mně přijde nejdůležitější ulevovat učitelům, když vlastně mají třeba náročnou tř́du. Vidím to ted'ka u jedné paní učitelky, která má tř́du třicet dětí se dvěma autisty, dalšími dětmi co mají espéučka [specifické poruchy učení pozn. autorů], poruchy chování nebo prostě hyperaktivní děti a tak. Prostě takový ten kotel opravdu všeho. [...] Tak přijdou kolikrát unavení, vyčerpaní, hotoví a potřebujou si prostě trochu ulevit." (školní psycholožka školy Lesní)

Jasně se zde ukazuje, že v proinkluzivních školách musí být školní psycholog každodenní běžnou součástí života školy. Teze o tom, že školní psycholog 
může úspěšně působit současně na více školách, rozhodně neplatí pro školy s vysokým podílem rizikových žáků a žáků s potřebou podpůrných opatření. Na našich školách totiž učitelé čelili nejrůznějším nečekaným situacím a afektům žáků a potřebovali, aby školní psycholog byl k dispozici tehdy, kdy to potřebují nejvíce. Na to školní psychologové reagovali snahou o viditelnost a snadnou dostupnost. Podobně o užitečných strategiích školních psychologů, například o užitečnosti krátkých konzultací, které respektují časovou strukturu práce a zátěž učitelů, hovoří i jiní autoři, kteří empiricky dokládají, že právě jejich snadná a rychlá dostupnost je ze strany učitelů velmi ceněna (Knoff, Sullivan, \& Liu, 1995).

Z uvedeného je zřejmé, že udržovat a rozvíjet vztahy s učiteli nemusí být pro školní psychology vždy snadné. Zdaleka ne všichni učitelé se s důvěrou na školní psychology obracejí, a to v našich školních psycholožkách vyvolávalo pocit nutnosti komunikovat s učiteli opatrně, s důrazem na bezpečnost obou stran a hlavně podpůrně.

„Je část učitelů, který jako psycholožku ne... Někdy si to raději učitelé udělají nějak sami a nepustí mě do toho. A je vidět takový to ,radši si to udělám sám, aby mně do toho nikdo nekecal' [...] Párkrát se ke mně dostal nějaký komentář od učitelů, jako že do toho špatně vstupuju nebo něco podobného nebo aby za mnou to dítě nechodilo. [...] Je potřeba komunikačně to nějak zvládnout, netlačit moc, zároveň říct, že tomu rozumím, co je těžký." (školní psycholožka školy Skleněné)

„Učitelé nejsou nastaveni na přímou kritiku. [...] Když je problém, musím nepřímo naznačovat." (školní psycholožka školy Lesní)

Požadavek na opatrnost $\mathrm{v}$ jednání s učiteli a důraz na podporu učitelů ze strany školních psychologů není novinkou výhradně související s proinkluzivním směřováním škol (srov. v českém prostředí např. Lazarová, 2008; Zapletalová, 2001), tento aspekt práce školních psychologů je ale nový svou flexibilitou, kterou v tomto ohledu musí školní psychologové prokazovat, aby nenarušili důvěru učitelů a neustále je motivovali k otevřenosti.

Druhý akcent tedy zdůrazňuje flexibilitu školních psychologů, jejich snadnou dostupnost, ochotu vyjadřovat učitelům porozumění a „ulevovat" jim od jejich zátěže. Ve snahách reagovat rychle na rozmanité potřeby učitelů i vedení škol se tak naši školní psychologové nezřídka dostávali do situací, pro jejichž řešení se necítili být kompetentními (viz dále). 


\section{Snaha vyhovět: intervence na hraně kompetencí}

Realita častějších incidentů ve školách a třídách s vysokou diverzitou žáků zvyšuje i tendenci učitelů žádat školní psychology o služby, které nejsou prŕmo v souladu se standardní náplní jejich práce, a tím i do jisté míry překračovat jejich profesionální kompetence.

„Někdy přijdou [učitelé - pozn. autorů] se sešitem: ,Já fakt ale nevím, jakou dát známku! Tak to nám tu strkají sešity, já jako psycholog, to tedy pro mě není jednoduchý. [...] Nebo třeba jakým způsobem naučit dítě počítat pod sebe, když to nejde, to jsou speciálněpedagogické techniky.“ (školní psycholožka školy Skleněné)

Zvýšené počty incidentů žáků také zvyšují pravděpodobnost objednávek typu „dohlédněte na toho žáka“ a staví školní psychology do pozice vykonavatelů sociální kontroly. Tlak učitelů i vedení škol na školní psychology, aby vystoupili ze své standardní role a intervenovali, kde je aktuálně třeba, na straně jedné posiluje přesvědčení učitelů, že školní psychologové jsou jim k užitku, na straně druhé se tak ale postupně deformuje představa o profesní roli školního psychologa. Spolu s tím se pak proměňuje jeho profesní identita ve vazbě na konkrétní školní kontext. Školní psychologové si tak čas od času potřebují vyjasnit vlastní roli a poslání a vyjednávat o nestandardních objednávkách ze strany učitelů i vedení školy, zvláště mají-li tyto objednávky kontrolní nebo represivní charakter.

„[...] některé děti se ocitají u psycholožky, protože to je jako... někdy fakt jakoby za trest. [...] To je situace, kdy se dítě u mě může opravdu objevit direktivně, když v hodině zlobí." (školní psycholožka školy Skleněné)

„Já jsem se dřív zapojovala i do toho vyšetřování, pokud třeba byla nějaká šikana nebo něco podobného. A to už ted'ka nedělám. Prostě jsem se proti tomu vymezila, že to není úplně moje role..." (školní psycholožka školy Lesní)

V proinkluzivních školách tedy existuje zvýšené riziko, že požadavky na školní psychology ze strany učitelů i vedení školy nebudou vždy odpovídat jejich původním představám o své práci a budou přesahovat jejich kompetence a standardní náplň práce. Jde zejména o administrativu spojenou se začleňováním žáků - se žádostmi o podpůrná opatření, individualizovanými plány podpory, s žádostmi o asistenty, o práci sociálního charakteru či o pedagogické či speciálněpedagogické intervence. 0 to více se zde akcentuje dovednost školních psychologů balancovat na hraně přijatelných a nepřijatelných 
objednávek a vyjednávat své poslání a roli ve škole tak, aby byly v souladu se standardním posláním školního psychologa a zároveň s potřebami konkrétní školy, resp. učitelů, žáků a rodičů.

\section{Zvládání nestandardních situací: intuice bez důkazů i jasná pravidla}

Je zřejmé, že nejen v námi zkoumaných školách si učitelé i školní psychologové musí stále častěji umět poradit i s takovými př́ípady, se kterými dosud neměli zkušenost a pro jejichž řešení nemají vymezené jasné postupy (srov. White \& Kratochwill, 2005). Nám se ukázalo, že stejně tak jako balancování na hraně svých kompetencí, je pro školní psychology „náročné“ umět si poradit i v nezvyklých či spíše ojedinělých situacích, s nimiž se dosud nesetkali nebo ani nemají povědomí o tom, že by se kdy ve školním prostředí objevily. V takových př́padech je zřejmé, že jejich intervence jsou poznamenány tzv. intelektuálním kutilstvím (srov. Štech, 2002), které je vlastně reakcí založenou na nereflektované zkušenosti a jednoduchém učení (single loop learning). Profesionální zvládání inkluzivního vzdělávání však vyžaduje reflektovanou praxi a tzv. dvousmyčkové učení (double loop learning) (Pol, 2007), založené na analýze jednotlivých př́ípadů.

V hektickém prostředí školy s vysokou diverzitou žáků se ale stává, že je potřeba prioritně „hasit požáry“ a přitom - logicky - zbývá méně času na reflexi a realizaci akčních výzkumů, které by přinesly důkazy o skutečných efektech práce učitelů a školních psychologů. $\mathrm{Z}$ rozhovorů se školními psychology a učiteli nebylo zřejmé, jakým způsobem plánují a vyhodnocují své intervence, činnosti a jejich dopady. Naše dotazy na toto téma zůstávaly bez konkrétních odpovědí.

Díky analýze dokumentů jednotlivých škol (z výročních zpráv a webových stránek) můžeme konstatovat, že školní psychologové prezentují svou práci prostřednictvím plánů, nabídek, činností a aktivit, které v minulém období realizovali nebo v budoucnu realizovat zamýšlejí, ale jen obtížně jsou dohledatelné důkazy o tom, jaké skutečné dopady má jejich práce na efektivitu či kvalitu školy. Přitom se má za to, že dokládání efektivity je zásadní podmínkou úspěšných intervencí školních psychologů (Knoff, Sullivan, \& Liu, 1995) a již po desetiletí se zvyšuje tlak na důkazy o účinnosti intervencí (Williams, Johnson, \& Sukhodolsky, 2005). V proinkluzivních školách, v nichž lze jen obtížně posuzovat úspěch žáků a kvalitu výuky pouze skrze vzdělávací výsledky žáků, nabývá problematika důkazů na vážnosti. Naše otázky směřované 
$\mathrm{k}$ hodnocení poradenské práce a $\mathrm{k}$ jejím dopadům probouzely $\mathrm{v}$ našich respondentech spíše rozpaky.

„Taky si občas ř́íám, jestli to děláme opravdu dobře. [...] Občas jsou takové ty sebereflektivní myšlenky, jak to máme a děláme. Máme takové nějaké obecnější přesvědčení, že tady těm dětem je třeba pomoct $v$ nějaké rozumné míre. Asi to nedokážu pojmenovat. [...] Já nevím, někdy se stane, že když chodím na schůzky vedení, že se občas k něčemu dostaneme. [...] Porovnat si to, co vlastně chceme, jak to tedy vlastně chceme a jestli je to opravdu tak dobře." (školní psycholožka školy Skleněné)

Dopady práce školních poradců a jejich užitečnost pro školu členové užšího vedení hodnotí kladně, avšak také bez konkrétních důkazů. Mnohdy převažující intuitivní ráz poradenských intervencí však neznamená, že učitelé, vedení škol a školní psychologové nevytvářejí určitá vlastní pravidla a více či méně formalizované postupy. Formalizované postupy, na kterých participují školní psychologové, se týkají například krizové intervence (jako reakce na afekty žáků), práce s tř́dami ve smyslu preventivních aktivit, depistáží, doučování nebo rozřazování žáků do tříd.

„[...] tak mají kantoři vyvěšený náš rozvrh, můj, zástupkyně a psycholožky, že nám ho sem dají. [...] Tak já jsem s ním chodil po zahradě, M. [psycholožka - pozn. autorů] se s ním procházela..." (ředitel školy Skleněné)

„[...] v první řadě to řeší třídní učitel. Pokud zjistí, že to přerůstá jeho možnosti, tak od toho jsou pedagogické rady, nebo má pocit, že by bylo vhodné, aby do toho vstoupila školní psycholožka... Pak si tedy učitel rozhodne sám, jestli osloví psycholožku. [...] A pokud se zjistí, že to $\mathrm{k}$ ničemu nevede nebo má pocit, že je třeba zasáhnout hlouběji, tak jde za vedením školy." (zástupce ředitele školy Lesní)

Při tvorbě formalizovaných postupů, zvláště při krizových intervencích, mají školní psychologové silnou pozici. Stále však pro ně zůstává velkou výzvou najít dostatek času pro vyhodnocování intervencí v jednotlivých nestandardních situacích a celkově evaluace vlastní práce. Zdá se také, že další velkou výzvou zatím zůstávají výzkumné aktivity realizované př́mo v praxi (akční výzkumy), které by školním psychologům i učitelům pomohly nacházet a rozšiřovat praxí ověřené cesty k inkluzivnímu vzdělávání. Podobný přetrvávající deficit v práci školních psychologů zmiňuje i Farrell (2004), u nás pak Lazarová (2008) a Mareš (2016), kteří v těchto aktivitách vidí př́ležitost k organizačnímu učení a organizační změně ve škole. 


\section{Práce se třídami: základ úspěchu inkluzivního vzdělávání}

Nestandardní, resp. komplexní situace, které nemají jednoznačná řešení, jsou nezřídka důsledkem incidentů mezi žáky, či dokonce mezi žáky a učiteli. V inkluzivním prostředí může počet takových situací narůstat. Vedení škol si uvědomuje, že mnohým rizikům a incidentům plynoucím s vysoké diverzity žáků lze předcházet, a sází proto na práci se sociálním klimatem. Zkušenost totiž ukazuje, že mnoho žáků a jejich rodičů ještě není připraveno na respektování jinakosti.

„Furt su přesvědčený o tom, že klíčový jsou děcka. A děcka na to [inkluzi - pozn. autorů] nepřipravíte. Děti jsou ze svý podstaty jaký jsou, a musím říct, i zlý. Jak vycítí slabýho jedince, tak to děcko tam prostě zahyne..." (zástupce ředitele školy Lesní)

„Ted’ jsme museli přemluvit děcka, aby třeba pomohly té K. o berlích do schodů. A to by ses divila, některý děcka řekly ,ne' a šlo to z rodin. Maminka řekla ,ne, žádný pomáhání, vůbec jim nepomáhejte. Mně maminka řekla, že tady nemá [tělesně postižené dítě - pozn. autorů] co dělat, prostě jí pomáhat nebudem." (ředitel školy Skleněné)

Preventivní práce učitelů i školní psycholožky s jednotlivci i s celými skupinami, resp. práce s klimatem ve třídách, je opatřením, které je zejména ve škole Skleněné až direktivně vyžadováno. Vedení této školy od třídních učitelů požaduje pravidelnou práci s tř́́dami a vytváří tak další důležitý prostor pro školní psycholožku, která po dohodě s učiteli vnáší do práce se třídami psychologická témata a psychologické způsoby práce (např. psychohry, reflektivní techniky apod.). Ve škole Lesní jsou to pak např. adaptační kurzy pro nově vznikající šesté třídy či relaxační chvilky pro žáky s ADHD syndromem.

„Na prvním stupni musí začínat týden tak, že si učitelka s děckama sedne jako máma. Máme ve třídách polštáře, pokecají. A na druhým stupni je přímo hodina natvrdo ,Domeček‘ V rozvrhu. Tam je pole pro jednání pro třídního učitele. A pole pro psycholožku, pole pro prevenci. [...] Všechno k řešení směřujem do ,Domečku“.” (ředitel školy Skleněné)

Školy tedy intenzivně hledají nové způsoby práce s třídami, i když jde někdy spíše o reaktivní intervence (než o prevenci) na nenadálou situaci či nevhodné chování dětí $\mathrm{k}$ některému ze spolužáků. Jiné, ucelené a osvědčené programy, jsou pak vnímány jako nezbytná prevence a jsou ukotveny v chodu školy. I když je opět jen obtížné hledat důkazy o efektech takové práce, 
po několikaletých zkušenostech jsou školy (vedení, učitelé i školní psychologové) přesvědčeny o tom, že tato cesta - práce s klimatem - je nejlepší investicí do budoucna, chtějí-li nadále přijímat všechny žáky bez rozdílu. S rodiči se v tomto ohledu pracuje spíš jen okrajově - jsou informováni a žádáni o spolupráci a výchovné intervence ve vztahu k vlastním dětem. Za pozornost stojí i to, že se školy snaží posilovat komunikaci s obcí (lépe se to patrně daří v menších obcích) a zapojovat rodiče do dění ve škole prostřednictvím různých aktivit, vytvářením symbolů školy apod. Školní psychologové mají při organizaci takových aktivit opět silné postavení a nezř́ídka přispívají svými nápady a zkušenostmi. Informují rodiče a veřejnost o své práci a o různých tématech (také o inkluzivním vzdělávání) např́íklad prostřednictvím nástěnek, zpráv ve zpravodaji školy, v obecním zpravodaji apod.

Zdá se, že obě námi sledované školy tak splňují jeden z hlavních požadavků kladených nově na všechny, nejen české, školy. Cíleně nezaměřují pozornost pouze na žáky se speciálními vzdělávacími potřebami (resp. s potřebou podpůrných opatření), ale preventivně pečují o celkové klima ve třídách (srov. NASP, 2010), a je zřejmé, že školní psychologové sehrávají v těchto snahách zásadní roli.

\section{Závěrem}

Naplňování ideálu inkluzivního vzdělávání se v běžné praxi neobejde bez problémů. Učitelé a ředitelé škol v ČR si opakovaně stěžují na nedostatek finančních zdrojů, na nemožnost individualizovat výuku při relativně vysokých počtech žáků ve třídách, na nedostatek asistentů pedagogů a chybějící podporu jejich působení ve školách, na obtížnou spolupráci s některými rodiči - a to vše v kontextu nikdy nekončícího hledání toho, co se vlastně v inkluzivním vzdělávání osvědčuje a funguje (Analýza, 2009; Lazarová, Pol, \& Sedláček, 2015; Valentová, Koutská, \& Langer, 2015). Kromě toho se ukazuje, že školní psychologové fungují v kontextu nedostatečně saturovaném českými odbornými zdroji, které by nabízely výsledky relevantních výzkumů a doporučovaly fungující postupy, jak zvládat diverzitu žáků ve školách a ve třídách. ${ }^{8}$

Existuje sice celá řada projekty podporovaných snah o prezentaci př́kladů dobré praxe či o tvorbu metodik pro práci asistentů pedagoga i učitelů (např. projekt Systémová podpora inkluzivního vzdělávání, časopis Škola All Inclusive, webové stránky Inkluzivní vzdělávání o. s. Rytmus apod.), ale ne vždy mají výstupy z těchto snah přímočarou cestu do každodenního života škol, navíc se práce školních psychologů týkají jen okrajově. 
Za této situace se snad zřetelněji než kdy jindy v minulosti ukazuje nezastupitelnost každodenního působení školních psychologů ve školách. Jejich nezastupitelnosti jsou si vědomi nejenom členové užšího vedení na obou našich školách, ale i většina učitelů. Na obou školách se také jasně deklaruje, že bez vytvoření určitých podmínek - mezi které patří i kvalitní psychologický servis - nelze $\mathrm{k}$ inkluzi směřovat. Podobně to nakonec dokládá i celá řada zahraničních autorů (srov. Havey, 1998; Knoff, Sullivan, \& Liu, 1995).

Reálná náplň práce školních psychologů se na námi zkoumaných školách odvíjí od očekávání a potřeb té které školy i jednotlivých aktérů vzdělávání. Reflexi těchto očekávání i jejich naplňování jsme představili skrze pět „nových" aspektů práce školních psychologů, které sami naši respondenti považují za ty, jež nabývají na důležitosti v případě, že škola směřuje k ideálu inkluzivního vzdělávání. Z hlediska obsahu práce školní psychologové nevnímají zásadní změny ve své práci, ale spíše jen posuny v nejrůznějších ohledech (stále se věnují prioritně žákům a učitelům a jejich základními činnostmi jsou intervence, prevence, depistáž i diagnostika). Na důležitosti ale nabývá jejich práce $\mathrm{v}$ oblasti sociálních vztahů, které se $\mathrm{z}$ hlediska fungování proinkluzivně naladěných škol jeví jako „výhodná“ investice do budoucna. Rezervy práce školních psychologů lze s ohledem na naše data spatřovat $\mathrm{v}$ učení se z vlastních i zprostředkovaných zkušeností a v evaluaci jejich práce.

V dnešních, proinkluzivně naladěných školách, se tedy školní psychologové ani jiní poradci nemusejí obávat nedostatku práce. Naopak, směřování škol k inkluzi posiluje postavení školních psychologů ve škole, což ale „na oplátku" od nich vyžaduje flexibilitu (být k dispozici), schopnost improvizovat i vytvářet pravidla, nebát se riskovat (nést spoluodpovědnost za rozhodnutí, přebírat úkoly na hranici svých kompetencí) a opatrně vyrovnávat vztahy $\mathrm{k}$ učitelům i k vedení školy. Tyto, podle našeho mínění vysoké, nároky na kompetence, kvalitu jejich práce i osobní odpovědnost by si jistě zasloužily více pozornosti v diskusích o profesní specializaci školních psychologů, jejich dalším vzdělávání i systémové podpoře, která by jasněji vymezila či spíše zajistila jejich kontinuální působení ve školách.

\section{Literatura}

Adelman, H. S., \& Taylor, L. (2003). Rethinking school psychology. Journal of School Psychology, 41(1), 83-90.

Adelman, H., \& Tylor, L. (2014). Embedding school health into school improvement policy. International Journal of School Health 1(3), e24546. 
AEP - Association of Educational Psychologists (1999). Increasing inclusion: ASP position paper. Durham: The Association of Educational Psychologists.

Akční plán inkluzivního vzdělávání na období 2016-2018 (APIV). (2015). Praha: MŠMT. Dostupné z http://www.vzdelavani2020.cz/

Allan, J. (2008). Rethinking inclusive education: The philosophers of difference in practice. Dordrecht: Springer.

Analýza individuálního př́stupu pedagogů $k$ žákům se speciálními vzdělávacími potrebami. Závěrečná zpráva (2009). Praha: Člověk v tísni, o.p.s. Dostupné z http://www.msmt. $\mathrm{cz} /$ file/8169?highlightWords=Anal\%C3\%BDza+individu\%C3\%A1ln\%C3\%AD + p\%C5\%99\%C3\%ADstupu+pedagog\%C5\%AF+\%C5\%BE\%C3\%A1k\%C5\%AFm

Anthun, R., \& Manger, T. (2006). Effects of special education teams on school psychology services. School Psychology International, 27(3), 259-280.

Asociace školní psychologie (nedatováno). Náplň práce školního psychologa pro práci s rodiči, pedagogy a dalšími spolupracujícími subjekty. Dostupné z http://www.schoolpsychology.cz

Bartolo, P. A. (2010). Why school psychology for diversity? School Psychology International 31(6), 567-580.

Berger, P. L., \& Luckmann, T. (1999). Sociální konstrukce reality. Pojednání o sociologii vědění. Brno: Centrum pro studium demokracie a kultury.

Booth, T., \& Ainscow, M. (2007). Ukazatel inkluze. Rozvoj učení a zapojení ve školách. Praha: Rytmus. Dostupné z http://www.csie.org.uk/resources/translations/IndexCzech.pdf

Braden, J. S., DiMarino-Linnen, E., \& Good, T. L. (2001). Schools, society, and school psychologists: History and future directions. Journal of School Psychology, 39(2), 203-219.

Braun, R., Marková, D., \& Nováčková, J. (2014). Praktikum školní psychologie. Praha: Portál.

Farrell, P. (2004) School psychologists. Making Inclusion a Reality for All. School Psychology International, 25(1), 5-19.

Farrell, P. (2006). Developing inclusive practices among educational psychologists: Problems and possibilities. European Journal of Psychology of Education, 21(3), 293-304.

Florian, L. (2008). Inclusion: Special or inclusive education: Future trends. British Journal of Special Education, 35(4), 202-208.

Havey, J. M. (1998). Inclusion, the law, and placement decisions: Implications for school psychologists. Psychology in the Schools, 35(2), 145-152.

Kershner, R., \& Farrell, P. (2009). Psychology for inclusive education: New directions in theory and practice. London: Routledge.

Knoff, H. M., Sullivan, P., \& Liu, D. (1995). Teachers' ratings of effective school psychology consultants: An exploratory factor analysis study. Journal of School Psychology, 33(1), 39-57.

Lazarová, B. (2008). Školní psychologie v České republice po roce 1989. Československá psychologie, 52(5), 480-492.

Lazarová, B., Pol, M., \& Sedláček, M. (2015). Mezinárodní šetření Talis 2013. Souhrnná zpráva mapující pedagogické vedení ředitelů základních škol v ČR. Praha: Česká školní inspekce.

Lazarová, B., Hloušková, L., Trnková, K., Pol, M., \& Lukas, J. (2015). Řízení inkluze ve škole. Brno: Masarykova univerzita.

Lukas, J. (2012). Připravenost školy k inkluzivnímu vzdělávání. Praha: NÚV. Dostupné z: http:// www.nuv.cz/ae/pripravenost-skoly-k-inklusivnimu-vzdelavani 
Mareš, J. (1998). Situace školní psychologie v ČR. Školský psycholog, 8(1), 7-14.

Mareš, J. (2016). Školní psycholog jako výzkumník: zamyšlení nad možnostmi. Pedagogická orientace, 26(1), 5-23.

Mitchell, D. (2005). Sixteen proposition on the context of inclusive education. In D. Mitchell, (Ed.), Contextualizing inclusive education. Evaluating old and new international perspectives (s. 2-21). London: Routledge.

National Association of School Psychologists (NASP) (2010). Model for comprehensive and integrated school psychological services. Dostupné $\mathrm{z}$ http://www.nasponline.org/ standards/2010standards/2_PracticeModel.pdf

Ohera, F. (1936). Funkce školního psychologa. Znojmo: vlastním nákladem.

Pol, M. (2007). Škola v proměnách. Brno: Masarykova univerzita.

Soodak, L. C. (2003). Classroom management in inclusive settings. Theory into Practice, 42(4), 327-333.

Štech, S. (2002). Sonda do profese školního psychologa v ČR. In Novinky v pedagogické a školní psychologii. Sborník př́spěvků (s. 22-31). Zlín: Lingua.

Štech, S., \& Zapletalová, J. (2001). Kvalitativní analýza přístupu školních psychologů k profesi srovnání kasuistických studií. In Metodika práce školních psychologů na ŽS a Š̌ (s. 37-47). Praha: IPPP.

Štech, S., \& Zapletalová, J. (2013). Úvod do školní psychologie. Praha: Portál.

Valentová, I., Koutská, M., \& Langer, J. (2015). Asistenti pedagoga. In J. Michalík (Ed.), Sborník příspěvků z konference projektu Systémová podpora inkluzivního vzdělávání v ČR 2015 (s. 9-22). Olomouc: UP.

Vyhláška č. 197 ze dne 2. června 2016, Sb.

Williams, S. K., Johnson, C., \& Sukhodolsky, D. G. (2005). The role of the school psychologist in the inclusive education of school-age children with autism spectrum disorders. Journal of School Psychology, 43(2), 117-136.

White, J. L., \& Kratochwill, T. R. (2005). Practice Guidelines in school psychology: Issues and directions for evidence-based interventions in practice and training. Journal of School Psychology, 43(2), 99-115.

Zapletalová, J. (2001). Co dělá školní psycholog? Kritická místa profese. Pedagogika. Mimořádné číslo, 36-46.

\section{Changes in the work of school psychologists in pro-inclusive schools}

Abstract: One way in which schools can be encouraged in their direction towards inclusion in education is to strengthen the professional potential of schools through the establishment of new, counseling-oriented functions of pedagogical staff or other specialists. These specialists undoubtedly include school psychologists and our intention in this study is to explore how inclusive schooling is changing the view of school psychologists to their work. Based on empirical data (multiple case study) of two basic schools we will describe how school psychologists rebuild their work, how 
they perceive new expectations of teachers and leadership of their schools and how they look at their own role in supporting the school in coping with the increasing diversity of pupils.

Keywords: school counselling, school psychologists, inclusive education, basic schools

\section{Autoři}

doc. PhDr. Bohumíra Lazarová, Ph.D., Masarykova univerzita, Filozofická fakulta, Ústav pedagogických věd, Arna Nováka 1, Brno 603 00, e-mail: lazarova@phil.muni.cz

Mgr. Lenka Hloušková, Ph.D., Masarykova univerzita, Filozofická fakulta, Ústav pedagogických věd, Arna Nováka 1, Brno 603 00, e-mail: hlouskov@phil.muni.cz

prof. PhDr. Milan Pol, CSc., Masarykova univerzita, Filozofická fakulta, Ústav pedagogických věd, Arna Nováka 1, Brno 603 00, e-mail: pol@phil.muni.cz

Mgr. Kateřina Trnková, Ph.D., Masarykova univerzita, Filozofická fakulta, Ústav pedagogických věd, Arna Nováka 1, Brno 603 00, e-mail: trnkova@phil.muni.cz

Syslová, Z. (2017). Učitel v předškolním vzdělávání a jeho př́prava na profesi. Brno: Masarykova univerzita.

Jádrem monografie se stává téma kvality práce učitele mateřské školy především v souvislosti s kvalifikačními požadavky na tuto profesi. Hledá odpovědi na otázky: Co charakterizuje profesi učitele MŠ v současnosti a jaká je její perspektiva? Jak koncipovat přípravné vzdělávání, aby byli učitelé mateřských škol skutečnými odborníky na vzdělávání v měnících se podmínkách? Při hledání odpovědí na uvedené otázky autorka využívá přehledové studie dosavadních empirických zjištění k tomuto tématu v komparaci se zahraničními zkušenostmi. Prezentuje výsledky výzkumných šetření zaměřených na zkoumání reflexe jako růstové kompetence v přípravném vzdělávání a sledování schopnosti sebereflexe v souvislosti s pedagogickým výkonem učitelů mateřských škol ve vybraných aspektech. 